\title{
Technical Note \\ NRD: Nicotiana Resistance Database, a Comprehensive Platform of Stress Tolerance in Nicotiana
}

\author{
Yudong Chen ${ }^{1,+}$, Shuai Yang ${ }^{1,2,+}$, Jiaxuan $\mathrm{Li}^{3}$, Kesu Wei ${ }^{4}$ and Long Yang $1, * \mathbb{D}$ \\ 1 College of Plant Protection and Agricultural Big-Data Research Center, Shandong Agricultural University, \\ Tai'an 271018, China; sdauzbcyd@163.com (Y.C.); longtoutengs@163.com (S.Y.) \\ 2 Yuxi Zhongyan Tobacco Seed Co., Ltd., Yuxi 653100, China \\ 3 College of Information Science and Engineering, Shandong Agricultural University, Tai'an 271018, China; \\ lijiaxuanchn@outlook.com \\ 4 Upland Flue-Cured Tobacco Quality and Ecology Key Laboratory, CNTC, Guizhou Academy of \\ Tobacco Science, Guiyang 550081, China; weiks8816@163.com \\ * Correspondence: lyang@sdau.edu.cn; Tel.: +86-538-8241575 \\ + These authors contributed equally to this work.
}

check for updates

Citation: Chen, Y.; Yang, S.; Li, J.; Wei, K.; Yang, L. NRD: Nicotiana

Resistance Database, a

Comprehensive Platform of Stress

Tolerance in Nicotiana. Agronomy 2022, 12, 508. https://doi.org/ 10.3390 /agronomy12020508

Academic Editor: Elena Zuriaga

Received: 13 January 2022

Accepted: 14 February 2022

Published: 17 February 2022

Publisher's Note: MDPI stays neutral with regard to jurisdictional claims in published maps and institutional affiliations.

Copyright: (C) 2022 by the authors. Licensee MDPI, Basel, Switzerland. This article is an open access article distributed under the terms and conditions of the Creative Commons Attribution (CC BY) license (https:// creativecommons.org/licenses/by/ $4.0 /)$.

\begin{abstract}
Nicotiana is one of the most important economic crops and model plants; however, its growth is affected by various biotic and abiotic stresses. In this study, 27,142 potential resistance genes were identified in six Nicotiana species, belonging to fourteen gene families and transcription factors related to stress resistance. The results indicate that Nicotiana has a potential abundance resistance background to biotic and abiotic stress, and these genes could be used in resistance breeding in the future. Analyzing the genome sequences of 19 pathogens, 5,421,414 Single Nucleotide Polymorphisms and 1958 Simple Sequence Repeats of pathogens have been obtained. The abundance loci show that the biotic pathogens have a high variability and biodiversity. An open-access database, named the Nicotiana Resistance Database (NRD), has been developed as a user-friendly resistance research platform for Nicotiana. The platform provides theoretical and technical support for the resistance research, including the cultivation of resistant varieties, and the genetics and breeding of Nicotiana and relative species.
\end{abstract}

Keywords: Nicotiana; pathogens; stress tolerance; resistance genes; database

\section{Introduction}

Under natural or agricultural conditions, plants grow under various stresses rather than ideal conditions [1]. These stresses can be divided into biotic and abiotic stress [2]. Only by constantly adapting to the environment, adjusting their morphological structure and physiological metabolism, can plants survive and reproduce $[3,4]$. Plants can resist stresses and maintain their life processes through osmotic adjustment [5,6], biomembrane regulation [7], reactive oxygen metabolism [8], hormones [9,10], stress proteins [11,12], and cross-adaptation $[13,14]$. Nicotiana is commonly used as a model plant in the study of molecular plant-microbe interactions $[15,16]$; it is also a vital material for the cigarette industry, and thus is of high commercial value all over the world. However, stress conditions cause extensive losses to the application of Nicotiana $[17,18]$. The pathogens of Nicotiana diseases cause extensive damage to tobacco, especially various viral diseases, such as tobacco mosaic virus (TMV), potato virus Y (PVY), cucumber mosaic virus (CMV), among others [19,20]. Abiotic stress, such as heat, cold, drought, waterlogging, and freezing, has caused many productivity reductions [21].

Although stress has tremendous damaging effects on Nicotiana, it also brings about a series of research studies on Nicotiana resistance. The methods of transcriptome and point mutation analysis have been wildly used in CMV [22] and TMV [20] research, which could be used to reduce the harm caused by pathogens. In addition, some of the resistance genes 
have been found in different plant species, such as GbRLK from Gossypium [23], TaWRKY10 from wheat [24], and TaNAC2a from tobacco [25]. Furthermore, some vital families and transcription factors, such as protein kinase (PKinase) and v-myb avian myeloblastosis viral oncogene homolog (MYB), have been considered to play an important role in abiotic stress responses [26,27]. Nonetheless, these efforts are far from enough to reduce the occurrence of Nicotiana diseases and improve the yield of Nicotiana. The expression products of resistance genes from the same family have the same relatively conserved domain, which is also the functional unit and evolutionary unit of this family. The sequences and functions of potential resistance genes can be inferred from known domains. To further study tobacco resistance, comparative genomic studies should be conducted using the genome sequences of Nicotiana and its pathogens.

Due to the fast development of sequencing techniques, increasingly more genomes have been sequenced in the past few years. Here, we chose three flue-cured tobacco varieties (Nicotiana tabacum cv. K326, N. tabacum cv. Basma Xanthi, and N. tabacum cv. TN90), two ancestors of $N$. tabacum (N. sylvestris and N. tomentosiformis), a common model species (N. benthamiana), and 19 pathogens of Nicotiana [28-32] for this research. Based on these sequences of the hosts and pathogens, a series of bioinformatic and comparative genomic analyses could be performed, and this study commits to the excavation of resistance genes and the variation of pathogens.

\section{Materials and Methods}

\subsection{Data Sources}

Six Nicotiana genome sequences and 19 genome sequences of common pathogens were downloaded from the NCBI (http: / / www.ncbi.nlm.nih.gov/ (accessed on 28 December 2021)) or the EMBL (http:/ / www.ebi.ac.uk / (accessed on 15 December 2021)). The Nicotiana genome sequence information contains their source, size, and version; the pathogen genome sequence information includes their length and size (Tables 1 and 2). All information can be found in the Nicotiana Resistance Database (NRD, http:/ / biodb.sdau.edu.cn/NRD/index. $\mathrm{html}$ (accessed on 7 February 2022)). Some preliminary modifications to these data were performed by Perl scripts, i.e., merging their IDs and replacing all the lowercase letters with uppercase letters in the sequences.

Table 1. Information of six Nicotiana genomes.

\begin{tabular}{cccc}
\hline Latin Name & Genome Size/Gb & Version & Reference \\
\hline N. benthamiana & 2.63 & Niben.v0.4.4 & {$[28]$} \\
N. sylvestris & 2.22 & GCA_000393655 & {$[29]$} \\
N. tomentosiformis & 1.69 & GCA_000390325 & {$[29]$} \\
N. tabacum cv. Basma Xanthi & 3.74 & GCA_000715095 & {$[30]$} \\
N. tabacum cv. K326 & 3.73 & GCA_000715075 & {$[30]$} \\
N. tabacum cv. TN90 & 3.64 & GCA_000715135 & {$[30]$} \\
\hline
\end{tabular}

Table 2. Information of 19 Nicotiana pathogens.

\begin{tabular}{|c|c|c|c|c|c|}
\hline Pathogens & $\begin{array}{l}\text { Genome } \\
\text { Number }\end{array}$ & $\begin{array}{l}\text { Total Sequence } \\
\text { Length/bp }\end{array}$ & Pathogens & $\begin{array}{l}\text { Genome } \\
\text { Number }\end{array}$ & $\begin{array}{l}\text { Total Sequence } \\
\text { Length/bp }\end{array}$ \\
\hline $\begin{array}{c}\text { Alfalfa mosaic virus } \\
\text { (AMV) }\end{array}$ & 18 & 47,450 & $\begin{array}{c}\text { Tobacco leaf curl virus } \\
\text { (TLCV) }\end{array}$ & 7 & 16,505 \\
\hline $\begin{array}{l}\text { Tobacco curly stop virus } \\
\text { (BCTV) }\end{array}$ & 3 & 9025 & $\begin{array}{c}\text { Tobacco mosaic virus } \\
\text { (TMV) }\end{array}$ & 69 & 435,826 \\
\hline $\begin{array}{l}\text { Cucumber mosaic virus } \\
\text { (CMV) }\end{array}$ & 149 & 398,422 & $\begin{array}{c}\text { Tobacco necrosis virus } \\
\text { (TNV) }\end{array}$ & 7 & 26,095 \\
\hline $\begin{array}{l}\text { Chilli veinal mottle virus } \\
\text { (CVMV) }\end{array}$ & 7 & 68,945 & $\begin{array}{c}\text { Tomato ringspot } \\
\text { nepovirus } \\
\text { (TomRSV) }\end{array}$ & 6 & 30,410 \\
\hline
\end{tabular}


Table 2. Cont.

\begin{tabular}{|c|c|c|c|c|c|}
\hline Pathogens & $\begin{array}{l}\text { Genome } \\
\text { Number }\end{array}$ & $\begin{array}{l}\text { Total Sequence } \\
\text { Length/bp }\end{array}$ & Pathogens & $\begin{array}{l}\text { Genome } \\
\text { Number }\end{array}$ & $\begin{array}{l}\text { Total Sequence } \\
\text { Length/bp }\end{array}$ \\
\hline $\begin{array}{l}\text { Potato virus } X \\
(\text { PVX) }\end{array}$ & 20 & 127,819 & $\begin{array}{c}\text { Tobacco rattle virus } \\
\text { (TRV) }\end{array}$ & 22 & 101,787 \\
\hline $\begin{array}{l}\text { Potato virus } Y \\
\quad(P V Y)\end{array}$ & 110 & $1,065,081$ & $\begin{array}{c}\text { Tobacco streak virus } \\
\text { (TSV) }\end{array}$ & 25 & 66,613 \\
\hline $\begin{array}{c}\text { Tomato aspermy virus } \\
\text { (TAV) }\end{array}$ & 11 & 30,409 & $\begin{array}{c}\text { Tomato spotted wilt } \\
\text { virus } \\
\text { (TSWV) }\end{array}$ & 85 & 340,357 \\
\hline $\begin{array}{l}\text { Tomato black ring } \\
\text { nepovirus } \\
\text { (TBRV) }\end{array}$ & 6 & 24,870 & $\begin{array}{c}\text { Tobacco vein-banding } \\
\text { mosaic virus } \\
\text { (TVBMV) }\end{array}$ & 13 & 67,964 \\
\hline $\begin{array}{l}\text { Tobacco bushy top virus } \\
\text { (TBTV) }\end{array}$ & 8 & 26,472 & $\begin{array}{c}\text { Tobacco vein distorting } \\
\text { virus } \\
\text { (TVDV) }\end{array}$ & 2 & 12,012 \\
\hline $\begin{array}{l}\text { Tobacco etch virus } \\
\text { (TEV) }\end{array}$ & 6 & 57,012 & & & \\
\hline
\end{tabular}

\subsection{Comparative Analysis of the Pathogen Genomes}

A BLAST-Like Alignment Tool (BLAT) alignment [33] was performed to find similar sequences using the sequences of 19 different pathogens. Single Nucleotide Polymorphisms (SNPs) were detected on the identified similarities compared with the reference sequences. Simple Sequence Repeats (SSRs) in all these pathogen sequences were detected by finding the dimer, trimer, tetramer, pentamer, hexamer, and heptamer quantities in at least $12 \mathrm{bps}$. All the analyses were performed in-house using Perl or Python algorithms.

\subsection{Potential Resistance Genes in Nicotiana}

To identify the resistance genes in Nicotiana, 16 resistance families and transcription factors were collected from 25 previous reports (Table 3 and http:/ /biodb.sdau.edu.cn/ NRD/host_domain.html (accessed on 7 February 2022)). The Hidden Markov Models of these resistance genes were downloaded from the Pfam database (http:/ / pfam.xfam.org/ (accessed on 7 February 2022)) [34]. A hmmsearch using HMMER software [35] was performed to get the potential gene members of six Nicotiana species. The numbers of the potential resistance genes were counted and analyzed using Perl scripts. The functions of these genes were annotated through comparison with the Gene Ontology database (GO) [36] and Kyoto Encyclopedia of Genes and Genomes database (KEGG) [37]. The candidate genes related to environmental adaptation were identified according to the annotation results.

Table 3. Information of 16 resistance domains.

\begin{tabular}{ccc}
\hline Pfam No. & Resistance Domains & Sources \\
\hline PF02045 & NFYA & {$[38,39]$} \\
PF00847 & AP2, CBF1, NAC, MYB & {$[40]$} \\
PF03242 & LEA & {$[41]$} \\
PF01849 & NAC (NAM, ATAF and CUC) & {$[42]$} \\
PF04404 & ERF & {$[43]$} \\
PF00447 & HSF & {$[44]$} \\
PF00170 & bZIP & {$[45]$} \\
PF00266 & LOS5/ABA3 & {$[46]$} \\
PF00069 & Pkinase & {$[23]$} \\
PF00808 & NFYB & {$[47]$} \\
\hline
\end{tabular}


Table 3. Cont.

\begin{tabular}{ccc}
\hline Pfam No. & Resistance Domains & Sources \\
\hline PF08688 & SbpAPX & {$[48]$} \\
PF00036 & EF-hand & {$[49]$} \\
PF00249 & R2R3-MYB & {$[50]$} \\
PF00230 & AQP & {$[51]$} \\
PF03106 & WRKY & {$[24]$} \\
\hline
\end{tabular}

\subsection{Development of a Web-Based Platform}

The LAMP (Linux-Apache-MySQL-PHP/Python) framework was used to build the Nicotiana Resistance Database (NRD). HTML (Hyper Text Markup Language) scripts and web pages were constructed through Dreamweaver, and the web interface was run on an Apache webserver. The information on SSRs, SNPs, and the candidate genes were stored in MySQL databases. Furthermore, the PHP scripts and Python scripts were connected to the web pages and MySQL databases to obtain a complete framework. The NRD (http:/ / biodb.sdau.edu.cn/NRD/index.html (accessed on 7 February 2022)) has been set up on a World-Wide Web server allowing internet access with a web client. All data in NRD are freely available for all academic and non-commercial users. All the sources and results of Nicotiana and pathogens analysis in this research can be found and downloaded at NRD.

\section{Results}

\subsection{SNPs and SSRs in Nicotiana Pathogens}

The pathogen sequences contained a few RNA sequences, and their lengths were generally less than $1 \mathrm{Mb}$. We identified 5,421,414 potential SNPs in the pathogen sequences, and the number of SNPs ranged from 26.3 (BCTV) to 6709.55 (TMV) per sequence (Table 4). On average, there were $3261.26 \mathrm{SNP}$ loci in each sequence, and most sequences contained over 1000 loci. The PVY contained 33,472.87 SNP loci per sequence, with the highest average number, followed by the CMV and TMV. The results show high distribution abundance in different pathogen sequences. Moreover, common diseases, such as TMV, CMV, PVX, and PVY, had higher variation rates than other pathogens.

We detected 1958 SSRs in the sequences of the 19 pathogens (Table 5). The distribution of the SSRs in these pathogens ranged from 1.3 (TSV) to 5.9 (TMV) per sequence. Most sequences only contained one or two SSR feature element(s). The quantities of dimers and hexamers were higher than the other motifs. The TSWV, PVY, and TMV had over 100 SSRs, whereas the number of SSRs in the other pathogens only ranged from 5 (BCTV) to 56 (PVX).

Table 4. SNPs in 19 Nicotiana pathogens.

\begin{tabular}{cccc}
\hline Pathogens & Genome Number & SNP Number & Average \\
\hline Alfalfa mosaic virus (AMV) & 18 & 5151 & 286.17 \\
Tobacco curly stop virus (BCTV) & 3 & 79 & 26.33 \\
Cucumber mosaic virus (CMV) & 149 & 869,705 & 5836.95 \\
Chilli veinal mottle virus (CVMV) & 7 & 22,082 & 3154.57 \\
Potato virus X (PVX) & 20 & 86,399 & 4319.95 \\
Potato virus Y (PVY) & 110 & $3,682,016$ & $33,472.87$ \\
Tomato aspermy virus (TAV) & 11 & 834 & 75.82 \\
Tomato black ring nepovirus (TBRV) & 6 & 234 & 39.00 \\
Tobacco bushy top virus (TBTV) & 8 & 2307 & 288.38 \\
Tobacco etch virus (TEV) & 6 & 3054 & 509.00 \\
Tobacco leaf curl virus (TLCV) & 7 & 1166 & 166.57 \\
Tobacco mosaic virus (TMV) & 69 & 462,959 & 6709.55 \\
Tobacco necrosis virus (TNV) & 7 & 3647 & 521.00 \\
\hline
\end{tabular}


Table 4. Cont.

\begin{tabular}{cccc}
\hline Pathogens & Genome Number & SNP Number & Average \\
\hline Tomato ringspot nepovirus (TomRSV) & 6 & 1712 & 285.33 \\
Tobacco rattle virus (TRV) & 22 & 10,593 & 481.50 \\
Tobacco streak virus (TSV) & 25 & 16,888 & 675.52 \\
Tomato spotted wilt virus (TSWV) & 85 & 219,687 & 2584.55 \\
Tobacco vein-banding mosaic & 13 & 32,901 & 2530.85 \\
virus (TVBMV) & 2 & 0 & 0 \\
Tobacco vein distorting virus (TVDV) & 574 & $5,421,414$ & \\
Total & &
\end{tabular}

Table 5. SSRs in 19 Nicotiana pathogens.

\begin{tabular}{|c|c|c|c|c|}
\hline Pathogens & $\begin{array}{l}\text { Sequence } \\
\text { Number }\end{array}$ & $\begin{array}{c}\text { SSR } \\
\text { Number }\end{array}$ & Average & Feature Element \\
\hline Alfalfa mosaic virus (AMV) & 12 & 29 & 2.42 & ttttta tctgag \\
\hline Tobacco curly stop virus (BCTV) & 3 & 5 & 1.67 & tactgg \\
\hline Cucumber mosaic virus (CMV) & 39 & 50 & 1.28 & gt tg \\
\hline Chilli veinal mottle virus (CVMV) & 6 & 35 & 5.83 & attcgcg \\
\hline Potato virus $\mathrm{X}(\mathrm{PVX})$ & 19 & 56 & 2.95 & cttgtg \\
\hline Potato virus Y (PVY) & 110 & 557 & 5.06 & ttattag \\
\hline Tomato aspermy virus (TAV) & 8 & 31 & 3.88 & $\operatorname{tg}$ \\
\hline Tomato black ring nepovirus (TBRV) & 6 & 14 & 2.33 & gatttt \\
\hline Tobacco bushy top virus (TBTV) & 6 & 12 & 2 & gaagtg \\
\hline Tobacco etch virus (TEV) & 6 & 14 & 2.33 & aaagca \\
\hline Tobacco leaf curl virus (TLCV) & 6 & 11 & 1.83 & $\begin{array}{c}\text { tgttca gtaaatt aag } \\
\text { ttttgaa aaattca }\end{array}$ \\
\hline Tobacco mosaic virus (TMV) & 67 & 398 & 5.94 & caa \\
\hline Tobacco necrosis virus (TNV) & 7 & 17 & 2.43 & aac \\
\hline Tomato ringspot nepovirus (TomRSV) & 5 & 19 & 3.8 & tgtc \\
\hline Tobacco rattle virus (TRV) & 7 & 15 & 2.14 & tac \\
\hline Tobacco streak virus (TSV) & 18 & 23 & 1.28 & ta \\
\hline Tomato spotted wilt virus (TSWV) & 139 & 614 & 4.42 & aaaaca \\
\hline Tobacco vein-banding mosaic virus (TVBMV) & 13 & 54 & 4.15 & aggaac \\
\hline Tobacco vein distorting virus (TVDV) & 2 & 4 & 2 & acctca taagga \\
\hline Total & 479 & 1958 & & \\
\hline
\end{tabular}

\subsection{Potential Resistance Genes in the Nicotiana Genomes}

The six Nicotiana genomes ranged from $1.69 \mathrm{~Gb}$ to $3.74 \mathrm{~Gb}$, in which the potential resistance genes are identified (Table S1). Resistance genes from 16 families were collected as reference sequences in previous research; however, only 14 families and transcription factors have been found in the six Nicotiana species. Based on the 14 families and transcription factors, 27,142 genes were detected that might be related to abiotic stress resistance. Among these genes, 15,928 ( $58.68 \%$ of the total number) belong to the PKinase family, followed by the MYB family, containing 3695 genes (Figure 1).

According to our comparison of these genes with the GO and KEGG databases, a majority of the genes were associated with biological processes related to environmental adaptation in all six species. Most of the annotated genes belonged to four families. The PKinase family had 2374 genes, and the MYB, EF-hand, and WRKY families comprised of 1568 genes, 1045 genes, and 1038 genes, respectively. In addition, the three Nicotiana species, N. tabacum cv. K326, N. tabacum cv. Basma Xanthi and N. tabacum cv. TN90, had more resistance genes than the other species (Figure 1). 


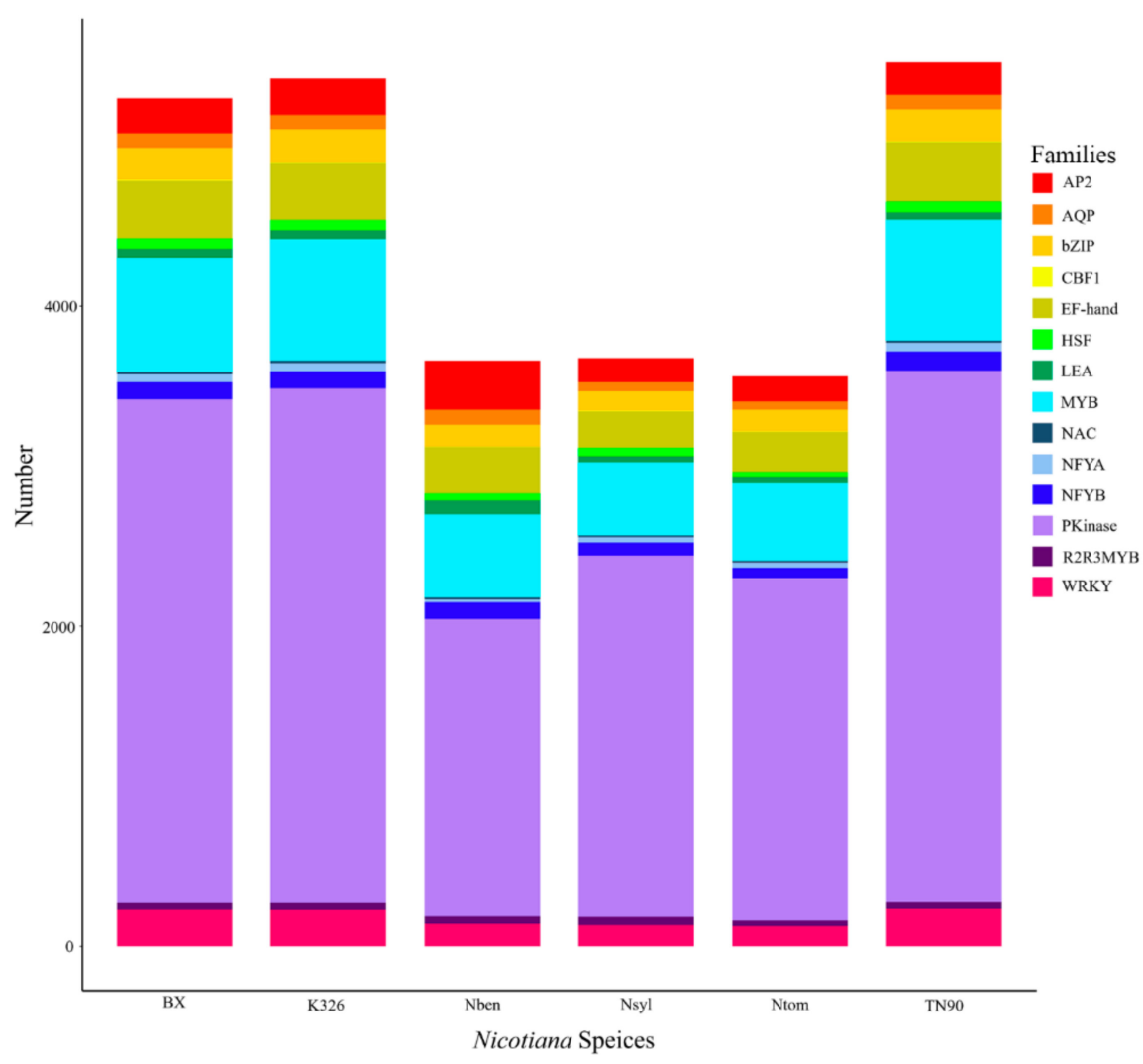

Figure 1. Distribution of resistance genes in the following Nicotiana species: BX, N. tabacum cv. Basma Xanthi; K326, N. tabacum cv. K326; Nsyl, N. sylvestris; Nben, N. benthamiana; Ntom, N. tomentosiformis; TN90, N. tabacum cv. TN90.

\subsection{Resistance Platform of Nicotiana}

The Nicotiana Resistance Database (NRD, http:/ / biodb.sdau.edu.cn/NRD/index. $\mathrm{html}$ (accessed on 7 February 2022)) was developed using seven primary interfaces, identified as HOME, HOST, PATHOGENS, TOOLS, DOWNLOAD, CONTACT, and LINK (Figure 2).

The HOME page gives a brief introduction and shows the overall framework of this platform, with a frame structure and several shortcut entrances.

The HOST page comprises four sections. Firstly, the Domains section shows the detailed information of the 16 resistance domains of the resistance families. Secondly, the Source section shows the detailed information of the six Nicotiana genomes used in this research. Thirdly, the Resistance genes section provides a search function to retrieve resistance genes via the option of Species, Domains, or ID. Subsequently, all the resistance genes can be downloaded through GENE DOWNLOAD. Fourthly, the results of GO and KEGG annotations can be found in the Annotation section. The KEGG annotation information can be obtained via the Species, Domains, ID, or KO option; alternatively, the GO annotation information can be retrieved through the Species, Domains, Type (GO, WEGO and InterProScan), or ID option.

The PATHOGENS page contains three sections. The Source section exhibits the detailed information of 19 pathogens. The SSR section provides an overview of the SSRs in the pathogen sequences, and provides search boxes to search for SSR loci via the Pathogens, ID, Motif, and Motif length options. The SNP loci can be searched through the Pathogens, Subject ID, Query ID, and Location options in the SNP section.

There are four common utility tools offered for the users on the TOOLS page. The SSR_detect model helps the user detect SSR loci from any sequence, and the CDS_protein model can transfer the nucleotide to an amino acid. In addition, the NRD_blast model provides a sequence alignment platform against the resistance genes in Nicotiana or the 
plant sequence derived from the NR database (8 October 2021). An outside tool, WEGO, also provides access.

The CONTACT page provides the authors' mailbox for users and the LINK page offers some valuable links to the relative research.

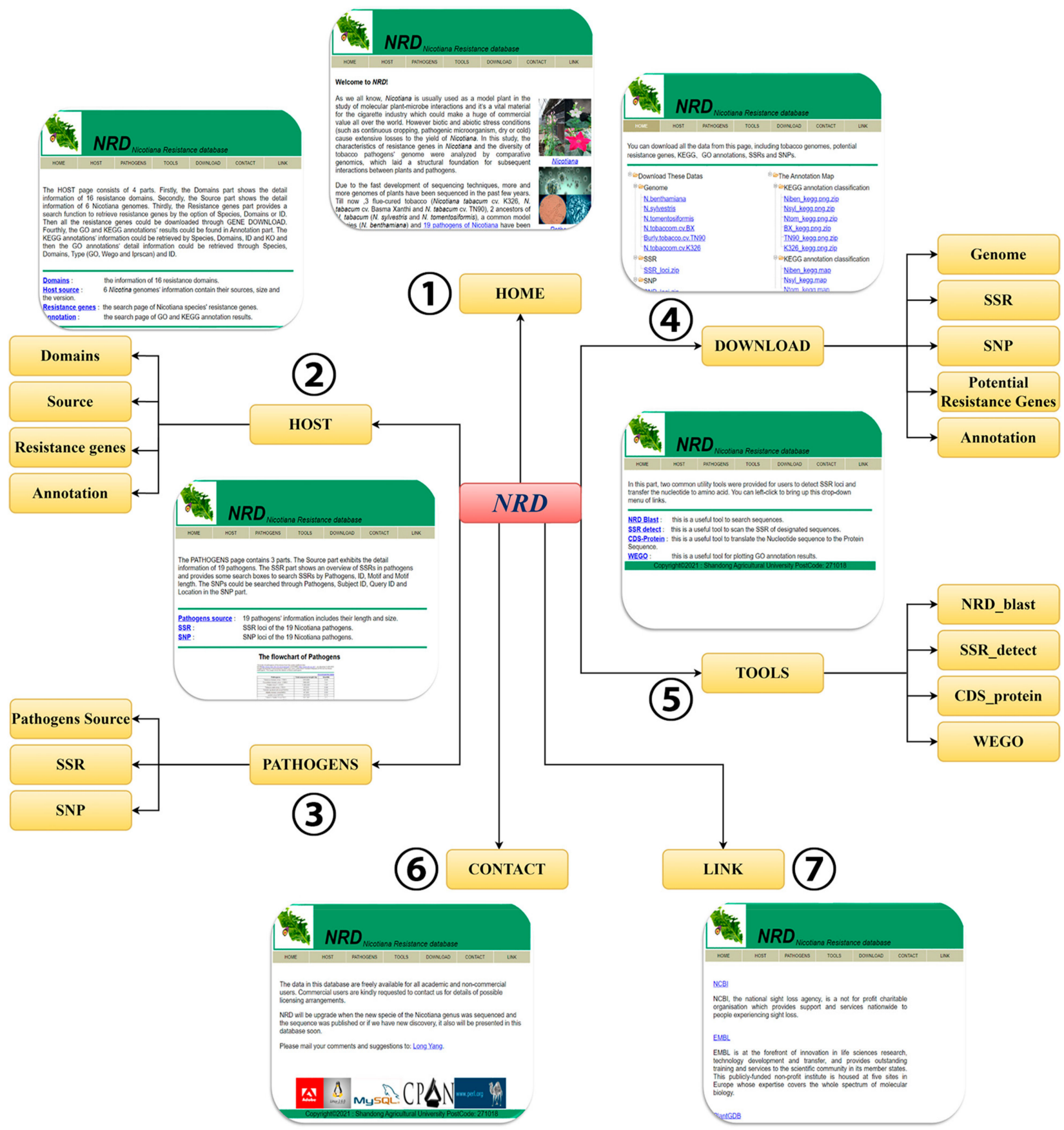

Figure 2. The framework of Nicotiana Resistance Database (NRD). (1) Home: introduction of the study and the frame-chart of NRD. (2) Host: provides the information of six Nicotiana genomes and 16 resistance families. Users can search the resistance genes in the drop-down menu. (3) Pathogens: provides the information of 19 pathogens and provides the users with search boxes for the Simple Sequence Repeats (SSRs) and Single Nucleotide Polymorphisms (SNPs) loci. (4) Download: the data can be downloaded on the page. (5) Tools: utility tools are offered to users to detect SSRs loci and transfer the nucleotide to an amino acid. (6) Contact: mailbox of the authors. (7) Link: some useful links. 


\section{Discussion}

\subsection{High Variation Rate of Pathogens Became a Big Challenge}

The results show that the pathogen sequences contain a large number of SNPs, and they are discrepant in different species. The high variation rate in the Nicotiana pathogens has led to the aggravation of Nicotiana diseases in recent years, and makes it very difficult to cultivate new resistant varieties [52,53]. Therefore, it is extremely necessary to combine bioinformatic analysis with experiments in the future. Meanwhile, the innovation of the Nicotiana variety resources requires the timely intervention of high-throughput sequencing technology.

\subsection{Abundance Potential Resistance Genes in Nicotiana Species}

A huge number of potential genes related to resistance were identified in the six Nicotiana species, which indicated there was a good genetic basis for resistance in tobacco, and these genes could be used in tobacco stress resistance breeding. The tobacco varieties N. tabacum cv. K326, N. tabacum cv. Basma Xanthi, and N. tabacum cv. TN90 exhibited more resistance genes than the others. This may be because N. tabacum is an allotetraploid, and this species deserves more research attention. Furthermore, the resistance genes in the wild species could also improve resistance in existing cultivation varieties.

PKinase is a family of ABA-activated protein kinases that plays an essential role in signal transduction and environmental adaptation [54]. The PKinase family has a high number of proteins/genes than other resistance gene families. This means the PKinase family provides a large number of resistance genes for Nicotiana breeding, and also suggests that the resistance of Nicotiana may be mediated by ABA. In addition, the EF-hand, MYB, and WRYK families also provide a lot of resistance sources for the genetic improvement of Nicotiana. The number of potential genes identified is far greater than the number of genes annotated, which is possibly due to the quality of the assembly affecting the subsequent annotation.

\subsection{Significance and Future Perspective}

The NRD is a user-friendly database, including HOST, PATHOGENS, TOOLS, and other modules, convenient for users to search and download. The database can summarize and display the resistance data of Nicotiana plants, and identify potential resistance genes and domains, as well as specific molecular markers in pathogens, all of which can help accelerate the research progress on the resistance of Nicotiana. Based on the NRD, the SSR and SNP markers could be used for gene location, genetic mapping, species diversity, and molecular assistant selection [55]. Especially, the NRD paves the way for resistance breeding in Nicotiana. The resistance domains and the resistance genes can be applied to many areas of biological research. The NRD will be upgraded when a new species of the Nicotiana genus is sequenced, and the sequence is published.

\section{Conclusions}

The stresses experienced during plant growth can cause enormous losses in yield and quality. Nicotiana, one of the most important economic crops and model plants, is no exception. In this study, 27,142 potential resistance genes were identified from six Nicotiana species by comparison with 16 resistance gene families and transcription factors, indicating that Nicotiana has a potentially rich background of resistance to biotic and abiotic stresses. Meanwhile, the genomic sequence markers of 19 pathogens were analyzed in this study, from which 5,421,414 SNPs and 1958 SSRs were obtained. Abundance loci show high variability and biodiversity in biological pathogens. On this basis, the Nicotiana Resistance Database (NRD, http://biodb.sdau.edu.cn/NRD/index.html (accessed on 7 February 2022)) has been developed into an open-access and user-friendly tobacco resistance research platform, and contains the genetic sequences of hosts and pathogens. This study provided a theoretical and technical support platform for resistance research, resistant variety cropping and the genetic breeding of Nicotiana and related species. 
Supplementary Materials: The following supporting information can be downloaded at: https: / / www.mdpi.com/article/10.3390/agronomy12020508/s1. Table S1. Potential resistance genes identified in six Nicotiana.

Author Contributions: Conceptualization, L.Y.; methodology, S.Y.; software, J.L.; validation, S.Y. and L.Y.; formal analysis, Y.C.; investigation, Y.C.; resources, Y.C.; data curation, S.Y. and J.L.; writing-original draft preparation, Y.C. and S.Y.; writing—review and editing, Y.C., S.Y. and K.W.; visualization, S.Y. and J.L.; supervision, L.Y.; project administration, L.Y.; funding acquisition, L.Y. and S.Y. All authors have read and agreed to the published version of the manuscript.

Funding: This work was supported by the Foundation of Shandong Province Modern Agricultural Technology System Innovation Team (SDAIT-25-01 to L.Y.) and Development Research on Selection and Experimental Planting of Cigar Varieties in Xishuangbanna (2019530000241047 to S.Y.).

Institutional Review Board Statement: Not applicable.

Informed Consent Statement: Not applicable.

Data Availability Statement: The datasets analyzed for this study can be found in the NRD (http: / / biodb.sdau.edu.cn/NRD/index.html (accessed on 7 February 2022)).

Conflicts of Interest: The authors declare no conflict of interest.

\section{References}

1. Passioura, J.B. Translational research in agriculture. Can we do it better? Crop Pasture Sci. 2020, 71, 517. [CrossRef]

2. Nouh, F.A.A.; Abdel-Azeem, A.M. Role of Fungi in Adaptation of Agricultural Crops to Abiotic Stresses; Springer: Berlin/Heidelberg, Germany, 2020; pp. 55-80.

3. Liu, C.; Huang, Y.; Wu, F.; Liu, W.; Ning, Y.; Huang, Z.; Tang, S.; Liang, Y. Plant adaptability in karst regions. J. Plant Res. 2021, 134, 889-906. [CrossRef]

4. Bussotti, F.; Pollastrini, M. Revisiting the concept of stress in forest trees at the time of global change and issues for stress monitoring. Plant Stress 2021, 2, 100013. [CrossRef]

5. Bai, X.; Dai, L.; Sun, H.; Chen, M.; Sun, Y. Effects of moderate soil salinity on osmotic adjustment and energy strategy in soybean under drought stress. Plant Physiol. Biochem. 2019, 139, 307-313. [CrossRef] [PubMed]

6. Masouleh, S.S.S.; Aldine, N.J.; Sassine, Y.N. The role of organic solutes in the osmotic adjustment of chilling-stressed plants (vegetable, ornamental and crop plants). Ornam. Hortic. 2020, 25, 434-442. [CrossRef]

7. Ghassemi, S.; Delangiz, N.; Asgari Lajayer, B.; Saghafi, D.; Maggi, F. Review and future prospects on the mechanisms related to cold stress resistance and tolerance in medicinal plants. Acta Ecol. Sin. 2021, 41, 120-129. [CrossRef]

8. Huang, H.; Ullah, F.; Zhou, D.X.; Yi, M.; Zhao, Y. Mechanisms of ROS Regulation of Plant Development and Stress Responses. Front. Plant Sci. 2019, 10, 800. [CrossRef]

9. Chalker-Scott, L.; Fuchigami, L.H. The Role of Phenolic Compounds in Plant Stress Responses; CRC Press: Boca Raton, FL, USA, 2018; pp. 67-80.

10. Bartwal, A.; Mall, R.; Lohani, P.; Guru, S.K.; Arora, S. Role of secondary metabolites and brassinosteroids in plant defense against environmental stresses. J. Plant Growth Regul. 2013, 32, 216-232. [CrossRef]

11. Al-Whaibi, M.H. Plant heat-shock proteins: A mini review. J. King Saud Univ. Sci. 2011, 23, 139-150. [CrossRef]

12. Farooq, M.; Wahid, A.; Kobayashi, N.; Fujita, D.; Basra, S.M.A. Plant drought stress: Effects, mechanisms and management. Sustain. Agric. 2009, 153-188.

13. Li, Z.G.; Min, X.; Zhou, Z.H. Hydrogen Sulfide: A Signal Molecule in Plant Cross-Adaptation. Front. Plant Sci. $2016,7,1621$. [CrossRef]

14. Boussiba, S.; Rikin, A.; Richmond, A.E. The role of abscisic Acid in cross-adaptation of tobacco plants. Plant Physiol. 1975, 56, 337-339. [CrossRef]

15. Hsu, C.T.; Lee, W.C.; Cheng, Y.J.; Yuan, Y.H.; Wu, F.H.; Lin, C.S. Genome Editing and Protoplast Regeneration to Study Plant-Pathogen Interactions in the Model Plant Nicotiana benthamiana. Front. Genome Ed. 2020, 2, 627803. [CrossRef]

16. Naalden, D.; Verbeek, R.; Gheysen, G. Nicotiana benthamiana as model plant for Meloidogyne graminicola infection. Nematology 2018, 20, 491-499. [CrossRef]

17. Mittler, R. Abiotic stress, the field environment and stress combination. Trends Plant Sci. 2006, 11, 15-19. [CrossRef]

18. Pasquet, J.C.; Chaouch, S.; Macadre, C.; Balzergue, S.; Huguet, S.; Martin-Magniette, M.L.; Bellvert, F.; Deguercy, X.; Thareau, V.; Heintz, D.; et al. Differential gene expression and metabolomic analyses of Brachypodium distachyon infected by deoxynivalenol producing and non-producing strains of Fusarium graminearum. BMC Genom. 2014, 15, 629. [CrossRef]

19. Tsedaley, B. A review paper on Potato virus Y (PVY) biology, economic importance and its managements. J. Biol. Agric. Healthc. 2015, 5, 110-126. 
20. Hoak, J. Tracking Tobacco Mosaic Virus Infection from Infected Seeds to Seedlings Confirms Seed Transmission in Tobacco (Nicotiana tabacum L.). Master's Thesis, Virginia Tech, Blacksburg, VA, USA, 2019.

21. Ratnarajah, V.; Gnanachelvam, N. Effect of Abiotic Stress on Onion Yield: A Review. Adv. Technol. 2021, 1, 147-160. [CrossRef]

22. Lu, J.; Du, Z.X.; Kong, J.; Chen, L.N.; Qiu, Y.H.; Li, G.F.; Meng, X.H.; Zhu, S.F. Transcriptome analysis of Nicotiana tabacum infected by Cucumber mosaic virus during systemic symptom development. PLoS ONE 2012, 7, e43447. [CrossRef]

23. Zhao, J.; Gao, Y.; Zhang, Z.; Chen, T.; Guo, W.; Zhang, T. A receptor-like kinase gene (GbRLK) from Gossypium barbadense enhances salinity and drought-stress tolerance in Arabidopsis. BMC Plant Biol. 2013, 13, 110. [CrossRef]

24. Wang, C.; Deng, P.; Chen, L.; Wang, X.; Hui, M.; Hu, W.; Yao, N.; Feng, Y.; Chai, R.; Yang, G.; et al. A Wheat WRKY Transcription Factor TaWRKY10 Confers Tolerance to Multiple Abiotic Stresses in Transgenic Tobacco. PLoS ONE 2013, 8, e65120. [CrossRef] [PubMed]

25. Tang, Y.; Liu, M.; Gao, S.; Zhang, Z.; Zhao, X.; Zhao, C.; Zhang, F.; Chen, X. Molecular characterization of novel TaNAC genes in wheat and overexpression of TaNAC2a confers drought tolerance in tobacco. Physiol. Plant. 2012, 144, 210-224. [CrossRef] [PubMed]

26. Roychoudhury, A.; Banerjee, A. Abscisic Acid Signaling and Involvement of Mitogen Activated Protein Kinases and CalciumDependent Protein Kinases During Plant Abiotic Stress. Mech. Plant Horm. Signal. Under Stress 2017, 1, $197-241$.

27. Roy, S. Function of MYB domain transcription factors in abiotic stress and epigenetic control of stress response in plant genome. Plant Signal. Behav. 2016, 11, e1117723. [CrossRef]

28. Bombarely, A.; Rosli, H.G.; Vrebalov, J.; Moffett, P.; Mueller, L.A.; Martin, G.B. A draft genome sequence of Nicotiana benthamiana to enhance molecular plant-microbe biology research. Mol. Plant Microbe Interact. 2012, 25, 1523-1530. [CrossRef]

29. Nicolas, S.; James, N.D.B.; Sonia, O.; Lucien, B.; Simon, G.; Nicolas, B.; Manuel, C.P.; Nikolai, V.I. Reference genomes and transcriptomes of Nicotiana sylvestris and Nicotiana tomentosiformis. Genome Biol. 2013, 14, 1-17.

30. Nicolas, S.; James, N.D.B.; Sonia, O.; Nicolas, B.; Lucien, B.; Adrian, W.; Simon, G.; Manuel, C.P.; Nikolai, V.I. The tobacco genome sequence and its comparison with those of tomato and potato. Nat. Commun. 2014, 5, 1-9.

31. Syu, M.; Denisenko, O.N.; Zelenina, D.A.; Fedorkin, O.N.; Solovyev, A.G.; Maiss, E.; Casper, R.; Atabekov, J.G. A novel open reading frame in tobacco mosaic virus genome coding for a putative small, positively charged protein. Biochimie 1993, 75, 659.

32. Christophe, R.; Mylène, D.-T.; Maurice, T.; Geneviève, B.; Suzanne, A.-M.; Francine, C.-D. Nucleotide Sequence of Potato Virus Y (N Strain) Genomic RNA. J. Gen. Virol. 1989, 70, 935-947.

33. Kent, W.J. BLAT-The BLAST-like alignment tool. Genome Res. 2002, 12, 656-664. [CrossRef]

34. Mistry, J.; Chuguransky, S.; Williams, L.; Qureshi, M.; Salazar, G.A.; Sonnhammer, E.L.L.; Tosatto, S.C.E.; Paladin, L.; Raj, S.; Richardson, L.J.; et al. Pfam: The protein families database in 2021. Nucleic Acids Res. 2021, 49, D412-D419. [CrossRef]

35. Finn, R.D.; Clements, J.; Eddy, S.R. HMMER web server: Interactive sequence similarity searching. Nucleic Acids Res. 2011, 39, W29-W37. [CrossRef]

36. Harris, M.A.; Clark, J.; Ireland, A.; Lomax, J.; Ashburner, M.; Foulger, R.; Eilbeck, K.; Lewis, S.; Marshall, B.; Mungall, C.; et al. The Gene Ontology (GO) database and informatics resource. Nucleic Acids Res. 2004, 32, D258-D261. [CrossRef] [PubMed]

37. Kanehisa, M.; Furumichi, M.; Sato, Y.; Ishiguro-Watanabe, M.; Tanabe, M. KEGG: Integrating viruses and cellular organisms. Nucleic Acids Res. 2021, 49, D545-D551. [CrossRef]

38. Li, W.-X.; Oono, Y.; Zhu, J.; He, X.-J.; Wu, J.-M.; Iida, K.; Lu, X.-Y.; Cui, X.; Jin, H.; Zhu, J.-K. The Arabidopsis NFYA5 transcription factor is regulated transcriptionally and posttranscriptionally to promote drought resistance. Plant Cell 2008, 20, $2238-2251$. [CrossRef]

39. Ni, Z.; Hu, Z.; Jiang, Q.; Zhang, H. GmNFYA3, a target gene of miR169, is a positive regulator of plant tolerance to drought stress. Plant Mol. Biol. 2013, 82, 113-129. [CrossRef]

40. Jaglo-Ottosen, K.R.; Gilmour, S.J.; Zarka, D.G.; Schabenberger, O.; Thomashow, M.F. Arabidopsis CBF1 overexpression induces COR genes and enhances freezing tolerance. Science 1998, 280, 104-106. [CrossRef]

41. Xiao, B.; Huang, Y.; Tang, N.; Xiong, L. Over-expression of a LEA gene in rice improves drought resistance under the field conditions. Theor. Appl. Genet. 2007, 115, 35-46. [CrossRef]

42. Hu, H.; Dai, M.; Yao, J.; Xiao, B.; Li, X.; Zhang, Q.; Xiong, L. Overexpressing a NAM, ATAF, and CUC (NAC) transcription factor enhances drought resistance and salt tolerance in rice. Proc. Natl. Acad. Sci. USA 2006, 103, 12987-12992. [CrossRef]

43. Liu, S.; Wang, X.; Wang, H.; Xin, H.; Yang, X.; Yan, J.; Li, J.; Tran, L.-S.P.; Shinozaki, K.; Yamaguchi-Shinozaki, K. Genome-wide analysis of ZmDREB genes and their association with natural variation in drought tolerance at seedling stage of Zea mays L. PLoS Genet. 2013, 9, e1003790. [CrossRef]

44. Bechtold, U.; Albihlal, W.S.; Lawson, T.; Fryer, M.J.; Sparrow, P.A.; Richard, F.; Persad, R.; Bowden, L.; Hickman, R.; Martin, C.; et al. Arabidopsis HEAT SHOCK TRANSCRIPTION FACTORA1b overexpression enhances water productivity, resistance to drought, and infection. J. Exp. Bot. 2013, 64, 3467-3481. [CrossRef] [PubMed]

45. Chen, H.; Chen, W.; Zhou, J.; He, H.; Chen, L.; Chen, H.; Deng, X.W. Basic leucine zipper transcription factor OsbZIP16 positively regulates drought resistance in rice. Plant Sci. 2012, 193-194, 8-17. [CrossRef] [PubMed]

46. Li, Y.; Zhang, J.; Zhang, J.; Hao, L.; Hua, J.; Duan, L.; Zhang, M.; Li, Z. Expression of an A rabidopsis molybdenum cofactor sulphurase gene in soybean enhances drought tolerance and increases yield under field conditions. Plant Biotechnol. J. 2013, 11, 747-758. [CrossRef] 
47. Han, X.; Tang, S.; An, Y.; Zheng, D.C.; Xia, X.L.; Yin, W.L. Overexpression of the poplar NF-YB7 transcription factor confers drought tolerance and improves water-use efficiency in Arabidopsis. J. Exp. Bot. 2013, 64, 4589-4601. [CrossRef]

48. Singh, N.; Mishra, A.; Jha, B. Over-expression of the peroxisomal ascorbate peroxidase (SbpAPX) gene cloned from halophyte Salicornia brachiata confers salt and drought stress tolerance in transgenic tobacco. Mar. Biotechnol. 2014, 16, 321-332. [CrossRef]

49. Wang, T.-Z.; Zhang, J.-L.; Tian, Q.-Y.; Zhao, M.-G.; Zhang, W.-H. A Medicago truncatula EF-Hand family gene, MtCaMP1, is involved in drought and salt stress tolerance. PLOS ONE 2013, 8, e58952. [CrossRef]

50. Zhang, L.; Zhao, G.; Xia, C.; Jia, J.; Liu, X.; Kong, X. A wheat R2R3-MYB gene, TaMYB30-B, improves drought stress tolerance in transgenic Arabidopsis. J. Exp. Bot. 2012, 63, 5873-5885. [CrossRef]

51. Zhou, S.; Hu, W.; Deng, X.; Ma, Z.; Chen, L.; Huang, C.; Wang, C.; Wang, J.; He, Y.; Yang, G.; et al. Overexpression of the wheat aquaporin gene, TaAQP7, enhances drought tolerance in transgenic tobacco. PLoS ONE 2012, 7, e52439. [CrossRef]

52. Fraile, A.; McLeish, M.J.; Pagan, I.; Gonzalez-Jara, P.; Pinero, D.; Garcia-Arenal, F. Environmental heterogeneity and the evolution of plant-virus interactions: Viruses in wild pepper populations. Virus Res. 2017, 241, 68-76. [CrossRef]

53. McLeish, M.J.; Fraile, A.; Garcia-Arenal, F. Evolution of plant-virus interactions: Host range and virus emergence. Curr. Opin. Virol. 2019, 34, 50-55. [CrossRef]

54. Tanaka, H.; Osakabe, Y.; Katsura, S.; Mizuno, S.; Maruyama, K.; Kusakabe, K.; Mizoi, J.; Shinozaki, K.; Yamaguchi-Shinozaki, K. Abiotic stress-inducible receptor-like kinases negatively control ABA signaling in Arabidopsis. Plant J. 2012, 70, 599-613. [CrossRef] [PubMed]

55. Bindler, G.; van der Hoeven, R.; Gunduz, I.; Plieske, J.; Ganal, M.; Rossi, L.; Gadani, F.; Donini, P. A microsatellite marker based linkage map of tobacco. Theor. Appl. Genet. 2007, 114, 341-349. [CrossRef] [PubMed] 